\section{Subacute toxicology studies on the aqueous fraction of the ethanol extract of the leaves of Cissampelos sympodialis Eichl. (Menispermaceae) in dogs}

\author{
Margareth F. F. Melo Diniz'; Hosana Bandeira Dos Santos²; \\ Maria Auxiliadora L. Cunha²; José Crispim Duarte'; Marcos \\ A. Morais ${ }^{3}$; Isac Almeida De Medeiros ${ }^{1 *}$
}

${ }^{1}$ Departamento de Ciências Farmacêuticas, Laboratório de Tecnologia Farmacêutica, Universidade Estadual da Paraiba, CP 5009, 58051-970, João Pessoa, PB, Brasil

${ }^{2}$ Hospital Universitário Lauro Wanderley

${ }^{3}$ Centro de Controle de Zoonoses do Município de João Pessoa isacmed@uol.com.br

\begin{abstract}
Cissampelos sympodialis Eichl. (Menispermaceae) has been investigated about its botanical, chemical, pharmacological and toxicological aspects in our laboratory. Previous acute toxicology studies demonstrated that in dogs as well as in Wistar rats, $5 \mathrm{~g} / \mathrm{kg}$, p.o., and $2 \mathrm{~g} / \mathrm{kg}$, i.p. of the aqueous fraction of the ethanol extract of the leaves of Cissampelos sympodialis (AFL), induced a significant increase in the phosphatase alkaline and gama glutamil tranferase (GGT) levels, that were completely reversed in 15 days after interruption of AFL treatment. The aim of the present work was to investigate the subacute toxicology effects induced by AFL in dogs. We used the methods proposed by Portaria 116/96 of the Secretaria Nacional de Vigilância Sanitária, which regulates studies of toxicity for phytomedicines in Brazil. Daily administration (p.o.) of AFL, $45 \mathrm{mg} / \mathrm{kg} / \mathrm{day}$ (5 times the dose used by human beings), during 4 weeks, was devoid of any effect on haematological (haemogram and platelets) and on blood biochemical parametes. In conclusion, the present study, using dogs, demonstrated that AFL, in a popularly used dose, by human beings, was devoid of any toxicological effect.
\end{abstract}

Cissampelos sympodialis Eichl. (Menispermaceae) a creeper plant which grows abundantly in northeaster Brazil, has been investigated about its botanical, chemical and pharmacological aspects in our laboratory. The therapeutic use of the water infusion of its root include the treatment of the diseases of the respiratory system (asthma, bronchits).

Previous studies, demonstrated that the aqueous fraction of the ethanol extract of the leaves (AFL) of Cissampelos sympodialis Eichl., a plant popularly used for asthma in Brazil, presented a tracheal smooth muscle relaxant activity in rats and an increase of the levels of cyclic adenosine monophosphate in guinea-pig alveolar leukocytes ${ }^{1,2,3}$. In Wistar rats, daily administration for 4 weeks (subchonic studies), in dose $9 \mathrm{mg} / \mathrm{kg}$ p.o (a dose popularly used by human beings) AFL was devoid of any toxicological effect. Nevertheless, at higher doses (45 and $225 \mathrm{mg} / \mathrm{kg}$, p.o), AFL induced a significant increase in AST and a globulin levels. The increase in AST levels was completely reversed in 15 and 30 days after interruption of AFL treatment (45 and $225 \mathrm{mg} / \mathrm{kg}$, respectely) ) $^{4.5}$.

The aim of the present work was realized to investigate the subchronic toxicology effects induced by AFL in dogs.

\section{Material and Methods}

Cissampelos sympodialis EICHL was collected from the botanical garden at the Laboratorio de Tecnologia Farmacêutica (LTF), UFPB, and was identified by the botany department of the Federal University of Paraíba where the voucher specimens are deposited (code Agra 1456). We used the methods proposed by the edict number 116/96" of the "Secretaria Nacional de Vigilância Sanitaria", which regulates studies of toxicity for phytomedicines in Brazil.

The leaves were dried at $35^{\circ} \mathrm{C}$ in an oven and pulverized. The powder was extractec with $50 \%$ ethanol in water and the resultant hydroalcoholic extract was dried at $70{ }^{\circ} \mathrm{C}$ using a rotaevaporator. When required, the AFL was dissolved in distiled water and used in the tests.

Subchronic studies were conducted in mongrel dogs (3 males and 3 females), weighting $(8.2-8.5 \mathrm{~kg}$ ) maintained in the Centro de Controle de Zoonoses ${ }^{7}$ from the municipality of João Pessoa, PB, Brazil.

Two groups of 6 dogs were used. While one group received water, the other was given the aqueous fraction of the ethanol extract of Cissampelos sympodialis in a dose of $45 \mathrm{mg} /$ $\mathrm{kg}$, p.o. daily for 4 weeks. Blood biochemical parameters were determined by standard chemical laboratory procedures by using the apparatus COBAS MIRA PLUS (Roche). Sodium and potassium levels were determined by a flame photometer (Tecnow 7000) and haematological parameters were evaluated by System 9000 (Serono Baker Diagnostics). Body weight and rectal temperature of the dogs were recorded initially and then once a week during the rest of the period.

The present studies were conducted to examine the toxicity of the aqueous fraction of the ethanol extract of the leaves of Cissampelos sympodialis (AFL) using dogs for subacute studies.

No significant difference was found in the rate of weight gain between the control and treated group (AFL $45 \mathrm{mg} / \mathrm{kg}$, p.o. for 4 weeks). For example, the mean (+ s.e.m.) increase in body weight in the control group were 7.0 and $7.2 \%$ for males and females (respectively), while those of the treated group were 7.3 and $6.9 \%$ (respectively).

In Table 1 and 2 are given the results of the haematological and blood biochemical evaluation of dogs treated with AFL for 4 weeks. AFL failed to induce any significant effect on haematological (Table 1) and on blood biochemical (Table 2) parameters (glucose, urea, creatinine, total cholesterol, 
Table 1. Haematological evaluation of dogs treated daily with tap water (before) or AFL (45 mg/kg) orally for 4 weeks

\begin{tabular}{|c|c|c|c|c|}
\hline \multirow{3}{*}{$\begin{array}{l}\text { Parameters } \\
\text { (Unit) }\end{array}$} & \multicolumn{4}{|c|}{ Treatment } \\
\hline & \multicolumn{2}{|c|}{ Males } & \multicolumn{2}{|c|}{ Females } \\
\hline & Before & After & Before & After \\
\hline Haemoglobin $(\mathrm{g} / \mathrm{dl})$ & $16.0 \pm 1.2$ & $16.0 \pm 1.1$ & $14.5 \pm 1.3$ & $15.0 \pm 0.9$ \\
\hline Haematocrit $(\%)$ & $49.6 \pm 4.2$ & $51.0 \pm 2.9$ & $44.0 \pm 4.0$ & $46.0 \pm 2.9$ \\
\hline $\mathrm{HC}(\%)$ & $33.0 \pm 0.6$ & $33.5 \pm 0.4$ & $33.0 \pm 0.1$ & $33.3 \pm 0.2$ \\
\hline Leucocytes $\left(10^{3} / \mathrm{mm}^{3}\right)$ & $11.0 \pm 0.9$ & $11.1 \pm 0.9$ & $11.6 \pm 0.4$ & $11.8 \pm 0.9$ \\
\hline Neutrofils (\%) & $71.0 \pm 1.8$ & $60.0 \pm 1.5$ & $60.0 \pm 2.8$ & $61.0 \pm 1.2$ \\
\hline Eosinofils (\%) & $2.0 \pm 0.6$ & $3.0 \pm 0.7$ & $3.0 \pm 1.1$ & $2.0 \pm 0.7$ \\
\hline
\end{tabular}

Values are expressed as mean \pm s.e.m. . $\mathrm{n}=3$ animals by sex. Test " $\mathrm{t}$ " Student $-5 \%$ of probability; MCV= mean corpuscular volume, MCH=mean corpuscular haemoglobin, $\mathrm{HC}=$ hemoglobin concentration

Table 2. Biochemical analysis of serum of dogs treated with tap water (before) or AFL ( $45 \mathrm{mg} / \mathrm{kg} / \mathrm{day}$ ) for 4 weeks

\begin{tabular}{l|l|l|l|l}
\hline \multirow{2}{*}{\begin{tabular}{l} 
Parameters \\
\cline { 2 - 5 }
\end{tabular}} & \multicolumn{4}{c}{ Treatment } \\
\cline { 2 - 5 } & Before & After & Before & After \\
\hline Glucose $(\mathrm{mg} / \mathrm{dl})$ & $74.0 \pm 9.0$ & $78.0 \pm 10.5$ & $79.0 \pm 5.1$ & $77.0 \pm 4.6$ \\
\hline Urea $(\mathrm{mg} / \mathrm{dl})$ & $28.0 \pm 3.9$ & $28.0 \pm 3.2$ & $27.7 \pm 4.6$ & $28.0 \pm 2.2$ \\
\hline Creatinine $(\mathrm{mg} / \mathrm{dl})$ & $0.9 \pm 0.04$ & $1.0 \pm 0.1$ & $0.9 \pm 0.1$ & $0.8 \pm 0.15$ \\
\hline Cholesterol $(\mathrm{mg} / \mathrm{dl})$ & $123 \pm 12.0$ & $125 \pm 10.8$ & $125 \pm 9.1$ & $122 \pm 3.5$ \\
\hline Triglycerides $(\mathrm{mg} / \mathrm{dl})$ & $60.0 \pm 3.1$ & $57.0 \pm 5.0$ & $56.0 \pm 6.0$ & $57.0 \pm 6.1$ \\
\hline AST $(\mathrm{U} / \mathrm{l})$ & $37.0 \pm 5.4$ & $39.0 \pm 3.0$ & $40.0 \pm 5.0$ & $36.0 \pm 3.2$ \\
\hline ALT $(\mathrm{U} / \mathrm{l})$ & $26.0 \pm 2.8$ & $24.0 \pm 3.0$ & $26.0 \pm 4.6$ & $25.0 \pm 3.5$ \\
\hline Alkaline phosphatase $(\mathrm{U} / \mathrm{l})$ & $58.3 \pm 5.0$ & $60.0 \pm 1.5$ & $60.0 \pm 2.8$ & $61.0 \pm 1.2$ \\
\hline Uric acid $(\mathrm{mg} / \mathrm{dl})$ & $0.4 \pm 0.10$ & $0.4 \pm 0.04$ & $0.33 \pm 0.04$ & $0.3 \pm 0.07$ \\
\hline Sodium $(\mathrm{mEq} / \mathrm{l})$ & $142 \pm 0.71$ & $141 \pm 0.41$ & $140 \pm 10.0$ & $139 \pm 3.5$ \\
\hline Potassium $(\mathrm{mEq} / \mathrm{l})$ & $4.9 \pm 0.18$ & $5.0 \pm 0.04$ & $5.1 \pm 0.70$ & $5.3 \pm 0.70$ \\
\hline Calcium $(\mathrm{mEq} / \mathrm{l})$ & $5.0 \pm 0.26$ & $4.9 \pm 0.16$ & $4.9 \pm 0.12$ & $5.1 \pm 0.11$ \\
\hline Magnesium $(\mathrm{mEq} / \mathrm{l})$ & $2.2 \pm 0.10$ & $2.3 \pm 0.100$ & $2.0 \pm 0.08$ & $2.1 \pm 0.10$ \\
\hline
\end{tabular}

Values are expressed as mean \pm s.e.m.. $\mathrm{n}=3$ animals by sex. Test " $\mathrm{t}$ " Student $-5 \%$ of probability; AST= aspartate transaminase. ALT= alanine transaminase

triglycerides, uric acid, total proteins and fractions, alkaline phosphatase, transaminases, sodium, potassium, calcium magnesium).

Considering all results, it may be concluded that by the oral route in a dose 5 times higher than that used in popular medicine, the aqueous fraction of the ethanol extract of the leaves of Cissampelos sympodialis was devoid of any toxicological effect. However, these results must be confirmed by histological studies, and by extending the studies to evaluate its effect on fertility and pregnancy and on adverse effects such as teratogenicity and carcinogenicity. Such studies are important as a large number of plants are known to produce toxic effects on chronic administration. Pyrrolizidine alkaloids containing plants of the Senecio species $^{8,9,10}$ and the plants of the family Convolvulaceae such as Ipomoea species, the toxic constituents of which are not completely yet known ${ }^{11}$ are some of the examples.

\section{References}

${ }^{1}$ Thomas G, Araújo CC, Agra MF, Melo-Diniz MFF. Preliminary studies on the hydroalcoholic extract of the root of $C$. sympodialis eichl in guinea-pig tracheal strips and bronchoalveolar leucocytes. Phytotherapy Research 1995; 9: 473-77

${ }^{2}$ Thomas G, Araújo CC, Duarte JC et al. Bronchodilatory activity of an aqueous fraction on the ethanolic extract of the leaves of 
C. sympodialis eichl in the guinea-pig. Phytomedicine. 1997; 4(3): 233-38

${ }^{3}$ Thomas G, Burnes F, Pyne S et al. Characterisation of an extract from the leaves $C$. sympodialis eichl on spontaneous tone of isolated trachea,cyclic nucleotide phosphodiesterase activy and intracellular camp. Phytotherapy Research. 1997; 11: 496-99

${ }^{4}$ Melo-Diniz MFF, Malta-Junior A, Ribeiro EAN, Santos HB, Medeiros IA. Acute and subacute toxicology studies on the acqueous fraction of the ethanol extract of the leaves of Cissampelos sumpodialis eichl. (Menispermaceae) in rodents. Bolletino Chimico Farmaceutico da Rivista di Scienze Farmaceutiche e Biologiche. 1999; 138 (2): 256

${ }^{5}$ Melo-Diniz MFF, Malta-Junior A, Ribeiro EAN, Santos HB, Medeiros IA. Cissampelos sympodialis ethanolic extract: chronic toxicology studies of its aqueous fraction in rats. In IV Pharmatech: New Perspectives In Drugs Delivery Systems. Nata1(Rn): Brazil 1999; 84

${ }^{6}$ Secretaria de Vigilância Sanitária. Portaria No 116/96. Normas para Estudo de Toxicológicos e da Eficácia de Produtos Fitoterapêuticos. Diário Oficial da República Federativa do Brasil, Poder Executivo, Brasília, DF, 12 de agosto de 1996

${ }^{7}$ Melo-Diniz MFF, Santos HB, Cunha MAL, Morais MA, Duarte JC, Oliveira KM, Medeiros IA. Parâmetros hematológicos e bioquímicos de cães. Newslab 2000; 41: 134-41

${ }^{8}$ Schoental R. Health hazards of pyrrolizidine alkaloids - a short review. Toxicology Letters 1982; 10:323-26

${ }^{9}$ Goerger DE, Cheeke PR, Ramsdell HS, Nicholson SS, Buhler DR. Comparison of the toxicities of Senecio jacobada, Senecio vulgaris and Senecio glabellus in rats. Toxicology Letters. 1983; 15: 19-3

${ }^{10}$ Schwartsman S. Plantas venenosas e animais peçonhentos. $2^{\mathrm{a}}$ edição. Sarvier S/A Editora. São Paulo. 1992; 68-71

${ }^{11}$ Tokarnia CH, Döbereiner J, Silva MF. Plantas tóxicas da amazônia. Instituto Nacional da Pesquisa Amazônica, Manaus. 1979
O uso das plantas medicinais sob prescrição médica: pontos de diálogo e controvérsias com o uso popular

\section{Sílvia Cardoso Bittencourt'; Sandra Caponi²; Miriam de Barcellos Falkenberg ${ }^{3 *}$}

1 Programa de Pós-Graduação em Saúde Pública, Universidade Federal de Santa Catarina

${ }^{2}$ Departamento de Saúde Pública, Universidade Federal de Santa Catarina

${ }^{3}$ Departamento de Ciências Farmacêuticas, Universidade Federal de Santa Catarina, Campus Universitário Trindade, 88040-900, Florianópolis, SC, Brasil

miriam@ccs.ufsc.br / scb@repensul.ufsc.br

\section{Resumo}

As plantas medicinais têm sido utilizadas sob os critérios dos conhecimentos popular e científico em diferentes contextos terapêuticos. O conhecimento científico algumas vezes tem entrado em conflito com o conhecimento popular, porém, em outras ocasiões tem havido uma busca de diálogo entre ambos. Foram analisadas as falas de participantes de três eventos técnico-científicos sobre plantas medicinais no ano de 1999 no estado do Paraná. Observamos que nesses eventos, houve uma busca de diálogo entre os representantes dos conhecimentos popular e científico, na busca da construção de um conhecimento que viabilize o uso das plantas medicinais de uma forma segura pela população.

\begin{abstract}
Medicinal plants are being used in different contexts as a therapeutic resource. Some times the scientific knowledge is in conflict whit popular knowledge, but in another occasions we found a dialogue between them. In this study, where analyzed the talks of participants in three events about medicinal plants in State of Paraná (Brazil) in the year of 1999. We observed that in those events, although controversies/conflicts exist between representatives of popular and scientific knowledge, a dialogue is happening, trying to reach a safe and efficient medicine to population.
\end{abstract}

As plantas medicinais vêm sendo utilizadas como recurso terapêutico para intervir no processo saúde/doença em diferentes sociedades, pela população em geral, e por profissionais especializados ${ }^{4,5,8}$. Atualmente, têm obtido espaço na terapêutica biomédica a partir do seu estudo sob critérios científicos para o desenvolvimento de fitoterápicos. No Brasil, instituições governamentais e não governamentais, de ensino, 